\title{
The role of alveolar type II cells in swine leptospirosis ${ }^{1}$
}

\author{
Ângela P. Campos ${ }^{2 *}$, Dayane F.H. Miranda²,Geórgia B.B. Alves², Micherlene S. \\ Carneiro $^{2}$, Maria G. Prianti' ${ }^{2}$, Larissa M.F. Gonçalves ${ }^{3}$, Vanessa Castro ${ }^{4}$ \\ and Francisco A.L. Costa ${ }^{2 \dagger}$
}

\begin{abstract}
Campos A.P., Miranda D.F.H., Alves G.B.B., Carneiro M.S., Prianti M.G., Gonçalves L.M.F., Castro V. \& Costa F.A.L. 2015. The role of alveolar type II cells in swine leptospirosis. Pesquisa Veterinária Brasileira 35(7):620-626. Setor de Patologia Animal, Departamento de Clínica e Cirurgia Veterinária, Universidade Federal do Piauí, Campus da Socopo S/N, Teresina, PI 64.049-550, Brasil. E-mail: angelapiauilino@hotmail.com

This study aimed to investigate a possible relationship between alveolar type II cells and the inflammatory response to infection with Leptospira spp., and thus comprise a further element that can be involved in the pathogenesis of lung injury in naturally infected pigs. The study group consisted of 73 adult pigs that were extensively reared and slaughtered in Teresina, Piauí state, and Timon, Maranhão state, Brazil. The diagnosis of leptospirosis was made using the microscopic agglutination test (MAT) aided by immunohistochemistry and polymerase chain reaction. The MAT registered the occurrence of anti-Leptospira antibodies in $10.96 \%$ (8/73) of the pigs. Immunohistochemistry allowed for the visualization of the Leptospira spp. antigen in the lungs of $87.67 \%$ (64/73) of the pigs. There was hyperplasia of bronchus-associated lymphoid tissue and circulatory changes, such as congestion of alveolar septa, parenchymal hemorrhage and edema within the alveoli. Lung inflammation was more intense $(p=0.0312)$ in infected animals, which also showed increased thickening of the alveolar septa $(p=0.0006)$. Evaluation of alveolar type II (ATII) cells using an anti-TTF-1 (Thyroid Transcription Factor-1) antibody showed that there were more immunostained cells in the non-infected pigs (53.8\%) than in the infected animals (46.2\%) and that there was an inverse correlation between TTF-1 positive cells and the inflammatory infiltrate. There was no amplification of Leptospira DNA in the lung samples, but leptospiral DNA amplification was observed in the kidneys. The results of this study showed that a relationship exists between a decrease in alveolar type II cells and a leptospire infection. Thus, this work points to the importance of studying the ATII cells as a potential marker of the level of lung innate immune response during leptospirosis in pigs.
\end{abstract}

INDEX TERMS: Alveolar type II cells, immunohistochemistry, Leptospira spp., lung, swine.

RESUMO.- [0 papel das células alveolares tipo II na leptospirose suína.] Setenta e três suínos adultos de criação extensiva, abatidos em Teresina, no estado do Piauí e Timon, no estado do Maranhão, constituíram o grupo de es-

\footnotetext{
${ }^{1}$ Received on February 25, 2015.

Accepted for publication on May 12, 2015.

${ }^{2}$ Setor de Patologia Animal, Departamento de Clínica e Cirurgia Veterinária, Universidade Federal do Piauí (UFPI), Campus da Socopo, Teresina, PI 64049-550, Brazil.*Corresponding author: angelapiauilino@hotmail.com

${ }^{3}$ Departamento de Medicina Veterinária, UFPI, Campus Professora Cinobelina Elvas, Bom Jesus, PI 64900-000, Brazil.

${ }^{4}$ Laboratório de Doenças Bacterianas da Reprodução, Instituto Biológico de São Paulo, Avenida Conselheiro Rodrigues Alves 1.252, São Paulo, SP 04014-002, Brazil.
}

tudo. 0 diagnóstico da leptospirose foi realizado utilizando a técnica de soroaglutinação microscópica (MAT), auxiliada por imunoistoquímica e reação em cadeia pela polimerase. A SAM registrou a ocorrência de anticorpos anti-leptospiras em 10,96\% (8/73) dos suínos. A imunoistoquímica permitiu a visualização de antígenos de Leptospira spp. em pulmões de 87,67\% (64/73) dos suínos. Havia hiperplasia do tecido linfoide associado ao brônquio e alterações circulatórias como, congestão do septo alveolar, hemorragia parenquimatosa e edema no interior de alvéolos. Os focos de inflamações pulmonares eram mais numerosos $(p=0,0312)$ nos animais infectados, bem como o espessamento do septo alveolar $(p=0,0006)$. A quantificação de células alveolares tipo II marcadas pelo anticorpo anti-TTF-1 (Thyroid 
Transcription Factor-1) mostrou que existia mais células imunocoradas em suínos não infectados $(53,8 \%)$ comparados aos infectados $(46,2 \%)$ e uma correlação inversa em relação ao infiltrado inflamatório. Não houve amplificação de DNA de Leptospira spp. em amostras de tecido pulmonar, no entanto DNA leptospiral foi observado em rim. Os resultados deste estudo mostraram que existe uma relação entre a diminuição das células alveolares tipo II e a infecção por leptospiras. Dessa forma, este trabalho aponta para a importância do estudo dessas células, como um provável marcador da modulação da resposta imune inata do pulmão na leptospirose em suínos.

TERMOS DE INDEXAÇÃO: Células alveolares tipo II, imunoistoquímica, Leptospira spp., pulmão, suíno.

\section{INTRODUCTION}

The alveoli of mammals are composed of endothelial cells with metabolic functions that participate in gas exchange, alveolar macrophages that coordinate the body's defenses, interstitial fibroblasts that secrete extracellular matrix components to support the honeycomb structure of the matrix, alveolar type I cells that mediate gas exchange, and alveolar type II cells (ATII) that have secretory functions, proliferate and mediate innate immunity (Herzog 2008).

ATII cells are important sources of pulmonary surfactants (SP-A, SP-B, SP-C and SP-D). These lipoproteins prevent alveolar collapse (Halliday 2008), mediate innate immunity (Chroneos et al. 2010), regulate the function of inflammatory cells through the secretion of a variety of cytokines and chemokines (Faine 1999), secrete growth factors, such as vascular endothelial growth factor (VEGF) (Zissel et al. 2000, Ferrara et al. 2003), complement components (Singh et al. 1988) and adhesion molecules, and present antigens in the context of MHC class II (Cunningham et al. 1994) molecules, thus providing ATT cells with properties similar to those of antigen-presenting cells (Debbabi et al. 2005).

ATII cells account for $15 \%$ of total alveolar cells but only constitute $5 \%$ of the alveolar surface in humans (Crapo et al. 1982). Due to their location, ATII cells may be exposed to various infectious agents (Russell et al. 2008). However, little is known about the role of ATII cells in domestic species. In adult rodent lungs, these cells cycle every 28 to 35 days, and it is likely that the same mitotic rate also occurs in humans (Uhal 1997). These kinetics are accelerated in response to lung injury (Evans \& Hackney 1972).

Leptospirosis is a bacterial disease that affects the lungs (Lin et al. 1999), but the pathophysiology of pulmonary infections by leptospires is poorly understood. The role of the immune system during this infection has not been fully clarified. Leptospires are known to directly cause injury to parenchymal cells and the vascular endothelium through their secreted toxins (Carvalho et al. 2004), leading to alterations in coagulation factors and triggering bleeding diathesis that culminates with a pulmonary hemorrhages (Luks et al. 2003). Additional injury is likely to be caused by leptospire activation of innate and humoral and cellular adaptive immune responses (Faine et al. 1999, Naiman et al. 2002), along with the activation of the innate immune response (Werts et al. 2001).

Few studies have been undertaken examining the involvement of ATII cells in the modulation of the innate immune response during a Leptospira spp. lung infection. Thus, considering that ATII cells are involved in lung protection against gram-negative bacteria (Kannan et al. 2009), this study aimed to investigate the pulmonary changes in pigs that were naturally infected with Leptospira spp. by analyzing ATII cells and their relationship with the inflammatory response and leptospires antigens to establish if ATII cells were involved in the pathogenesis of lung injury.

\section{MATERIALS AND METHODS}

The study group consisted of 73 adult swine of mixed breeds (no definite breed) that were reared in an extensive system and slaughtered in the cities of Teresina in Piauí State and Timon in Maranhão State, Brazil. Infection with leptospires was diagnosed using the microscopic agglutination test (MAT) aided by immunohistochemistry (IHC) and polymerase chain reaction (PCR). The uninfected swine tested negative in the three technics.

The MAT was performed using a battery of antigens from the Autumnalis, Ballum, Bratislava, Canicola, Copenhageni, Grippotyphosa, Hardjo bovis, CTG Hardjo, Icterohaemorrhagiae, Pomona, Pyrogenes, and Tarassovi serovars. The serum reagent was defined as inducing 50\% agglutination of leptospires per microscopic field at $100 \mathrm{x}$ magnification. The serovar with the highest titer was considered reactive.

Fragments of lung tissue were formalin fixed and paraffin embedded and processed following the routine protocols of the Laboratory of Animal Pathology, Center for Agricultural Sciences, Federal University of Piaui (CCA/UFPI). The tissues were stained with hematoxylin-eosin (HE) and immunoperoxidase.

Sections of tissue were prepared and stained IHC using a polyclonal anti-Leptospira antibody (produced in the Laboratory of Animal Pathology of UFPI) and the EnVision + peroxidase system (Dako Comporation Carpinteria, CA, USA, catalog number K4002) for reaction amplification. Other sections were incubated with monoclonal anti-Napsin A (cod. NCL-L-Napsin A, Novocastra, Leica Biosystems Newcastle, United Kingdom) and anti-TTF-1 (Thyroid Transcription Factor-1) (cod. NCL-L-TTF-1, Novocastra, Leica Biosystems Newcastle, United Kingdom) antibodies. The negative control of the reactions were performed in one of the tissue sections with PBS instead of primary antibody. The reaction amplification was performed using the Ultravision LP Value Detection System, with HRP Polymer (ref. TL-125-HLS, LabVision Corporation, Thermo scientific, Fremont, CA 94539, USA). Stained

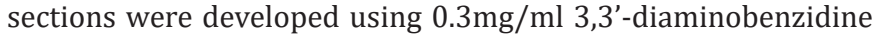
in PBS containing $0.06 \%$ hydrogen peroxide and were counterstained with Harris hematoxylin.

DNA was extracted and purified from samples of lung tissue using a Qiagen kit (QIAamp DNA Mini Kit 50, No. 51 304, Qiagen Biotecnologia Ltda, São Paulo, Brazil), following the manufacturer's instructions. To amplify DNA from Leptospira spp., the primers Lep-1 (5 'GGCGGCGCGTCTTAAACATG 3') and Lep-2-(5 'TTCCCCCCATTGAGCAAGATT 3') (Invitrogen ${ }^{\circledR}$, California, USA) [GenBank accession n. X17547.1] (Mérien et al. 1992) were used. The cycle DNA amplification was recommended by Richtzenhain et al. (2002). The amplified product (331 bp for the 16S rRNA of Leptospira spp.) was subjected to electrophoresis on a $1.5 \%$ agarose gel and stained with ethidium bromide. The bands 
were visualized on an ultraviolet transilluminator (300-320 nm) and photographed using the MiniBIS Pro photodocumentation system (DNR Bio-Imaging Systems Ltd., Jerusalem, Israel) in the Sector of Animal Pathology of UFPI. As a positive control, we used DNA extracts from cultures of serovar Icterohaemorragiae. As a negative control, we used a mixture of the reactants used in the PCR reaction without the initial DNA template.

We captured 30 random fields per section of lung tissue from eight infected and eight uninfected swine. Morphometric analyses were performed on the sections stained with hematoxylin and eosin and on those stained with immunoperoxidase using a computerized image analyzer (Qwin Leica D-1000, version 4.1, Department of Animal Pathology). The following parameters were measured: area of inflammatory infiltrate foci presents on tissue sections, thickening of alveolar septa mensured between two adjacent alveoli, number of ATII cells present in the alveolar wall and number of antigen-leptospires positive cells in lung parenchyma.

Statistical analysis was performed using the GraphPad Prism 5.0 (GraphPad Software, San Diego California, USA) software. We used the Mann-Whitney test for comparison between two groups and correlation analysis by linear regression. A significance level of $\mathrm{p}<0.05$ was considered to be statistically significant.

\section{RESULTS}

Eight (10.96\%) of 73 pigs had positive titers of anti-leptospira antibodies. Three samples reacted to the Grippotyphosa serovar (two in the 1:100 titration and one in the 1:400 titration), two samples reacted to the Icterohaemorrhagiae serovar (1:100), two samples reacted to the Canicola, Grippotyphosa, and Pyrogenes serovars (1: 100 titer), and one sample reacted to the Grippotyphosa and Hardjo OMS serovars (1:100 titer).

IHC analysis showed the Leptospira spp. antigen in lung tissue from 64 of the 73 pigs, of which eight were serologically positive and 56 serologically negative, for an overall positivity rate of $87.67 \%$. The antigens were detected in mononuclear cells of the alveolar septum and fibroblasts at the foci of inflammation, such as alveolar epithelial cells, bronchial and bronchiolar cells, smooth muscle cells of the bronchial wall and in the bronchial-associated lymphoid tissue. In nine serologically negative pigs, the Leptospira spp. antigen was not detected.

Inflammatory changes were present in all pigs, except for one negative pig. There were more inflammatory infiltrate foci $(\mathrm{p}=0.0312)$ in the lungs of the infected pigs (Fig.1) compared to the uninfected pigs. Increased thickening of the alveolar septum was observed in the infected pigs $(p=0.0006)$ (Fig.2) due to congestion, hemorrhage, and an inflammatory infiltrate consisting of lymphocytes, macrophages and fibroblasts. The inflammatory reaction was focally distributed, and its intensity varied from minimal to severe. In three pigs had hyperplasia of bronchial associated lymphoid tissue suggesting infection with Mycoplasma hyopneumoniae. In these animals we can not say that the changes in the number of alveolar type II cells were due solely to infection with Leptospira. If other pathogens also cause is change, further research should be done to confirm this possibility. Circulatory disorders such as parenchymatous hemorrhage, congestion and edema of the alveolar septa were more intense in the infected pigs.

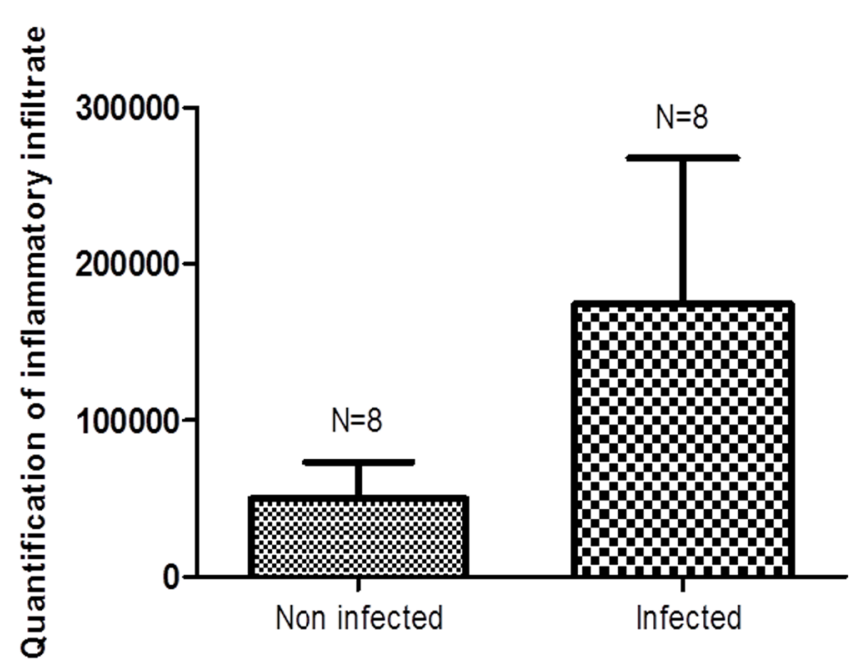

Fig.1. Morphometric analysis of the foci of inflammatory infiltration (HE) of lung tissue from uninfected pigs and from those naturally infected by Leptospira spp. A total of 30 random fields/pig were analyzed. $\mathrm{N}=$ number of animals. ${ }^{*} \mathrm{p}=0.0312$ (Mann-Whitney test).

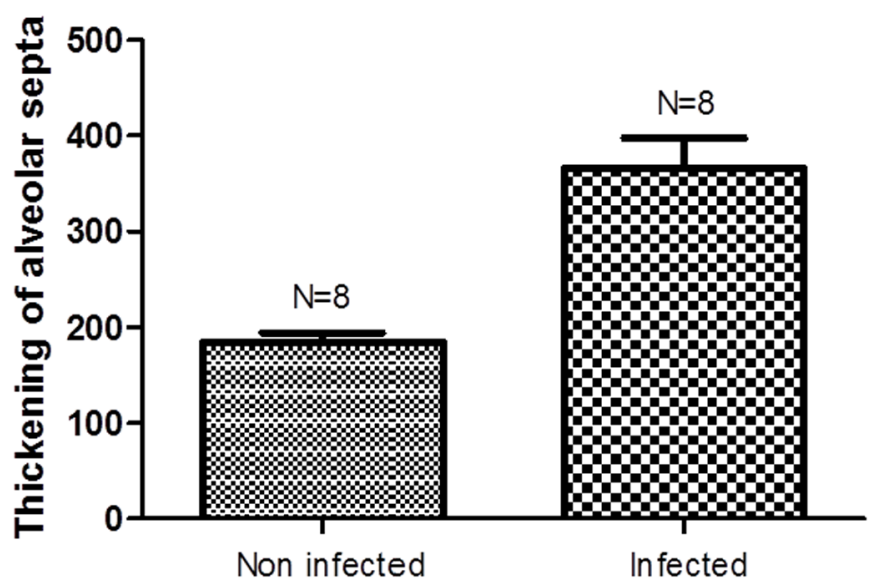

Fig.2. Morphometric analysis of alveolar septal thickening (HE) in lung tissue from uninfected pigs and those naturally infected by Leptospira spp. A total of 30 random fields/pig were analyzed. $\mathrm{N}=$ number of animals. ${ }^{*} \mathrm{p}=0.0006$ (Mann-Whitney test).

ATII cells were quantified through anti-TTF-1 staining (Fig.3), which showed that there were more immunostained cells (53.8\%) in the uninfected pigs compared to the infected pigs (46.2\%), but there was no significant difference. TTF-1 positive ATII cells also showed an inverse correlation with inflammatory infiltrates (Fig.4).

When ATII cells were stained with anti-Napsina A (Fig.5) in contrast to being stained with anti-TTF-1, there were more immunostained cells (56.6\%) in the infected pigs compared to the uninfected pigs (43.4\%), but there was no significant difference. A positive relationship between the levels of Napsina A-positive ATII cells and inflammatory infiltration was observed (Fig.6).

PCR was negative in samples of lung tissue, but there was amplification of leptospiral DNA in the kidney tissue of one pig. 


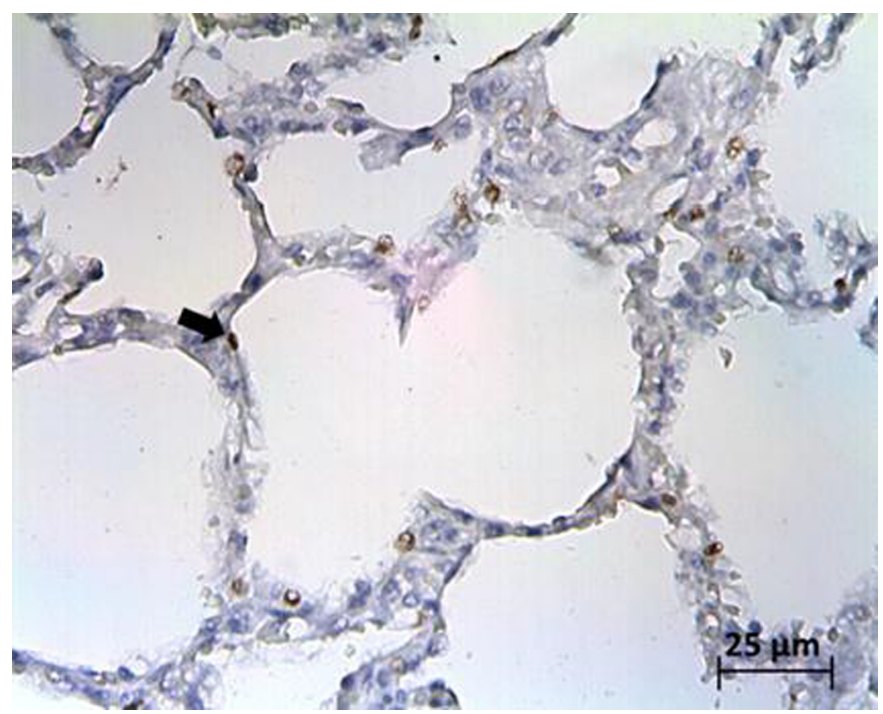

Fig.3. Alveolar type II cells positively stained with the anti-TTF-1 antibody in the lungs of pigs, as shown by immunohistochemistry.

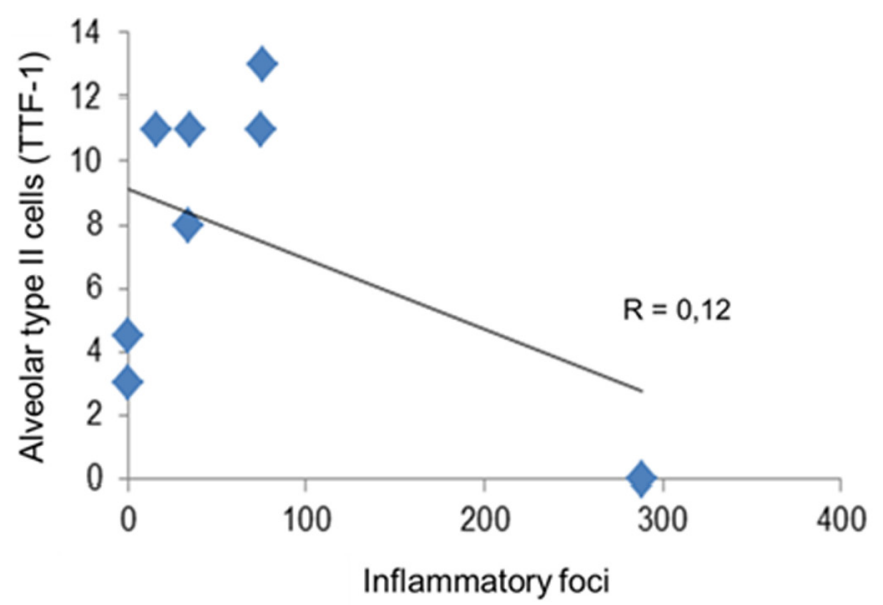

Fig.4. Correlation between ATII cells stained with the anti-TTF-1 antibody and inflammatory infiltration of the lungs of pigs naturally infected with Leptospira spp. *p=0.77.

\section{DISCUSSION}

The MAT indicated that $10.96 \%$ of the pigs studied were infected by Leptospira spp. This result was below the level detected through IHC detection of the Leptospira antigen (87.67\%), demonstrating that the IHC is more suitable technique for the diagnosis of leptospirosis using specific antibodies in formalin-fixed and paraffin-embedded tissues (Nakane \& Pierce 1966, Avrameas 1970). Thus, in pathological studies, this technique can complement a serological diagnosis to represent a more sensitive assay, as has been previously suggested (Nakane \& Pierce 1966). Techniques using the peroxidase enzyme as a marker allow antigens to be viewed even when fragmented or in the presence of other infectious agents (Avrameas 1970).

The detection of the Leptospira antigen in the lung tissue of serologically negative pigs (56 pigs) was most likely due to the limited number of Leptospira spp. serovars that were used in the MAT. Thus, if at any time the pigs has been

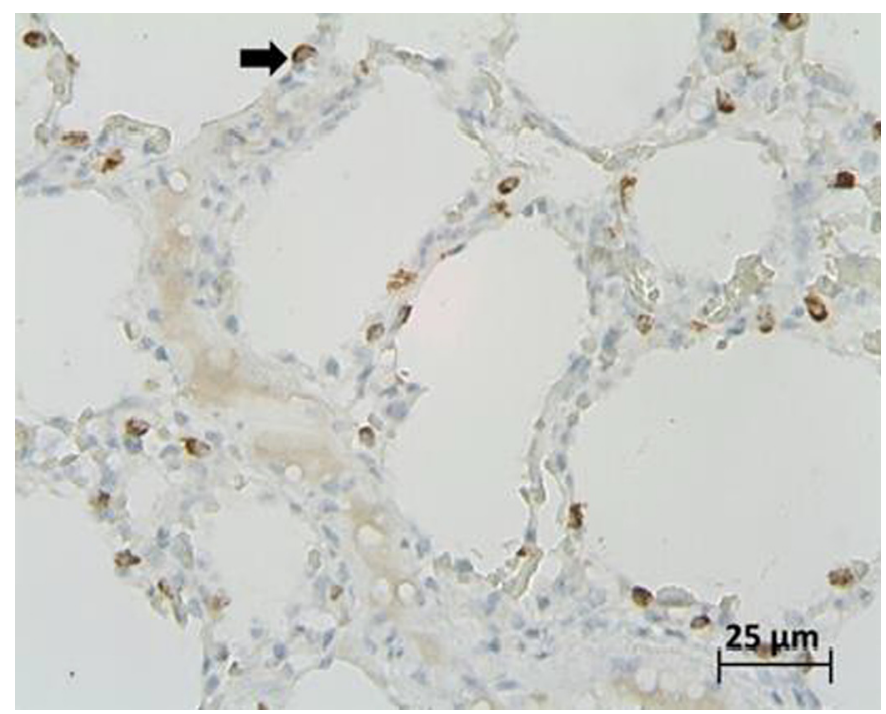

Fig.5. Alveolar type II cells positively stained with the anti-NapsinaA antibody in the lungs of pigs, as shown by immunohistochemistry.

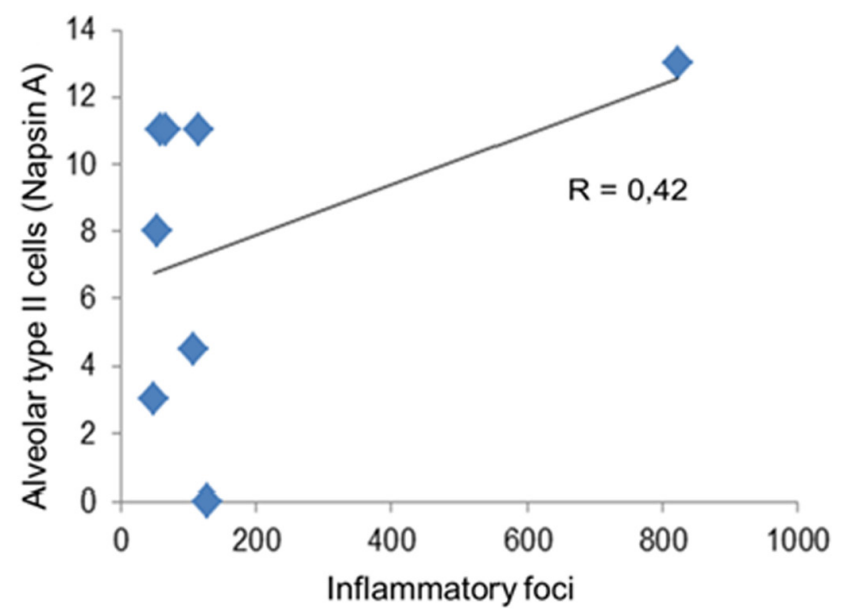

Fig.6. Correlation between ATII cells labeled with the anti-Napsina antibody and inflammatory infiltration of the lungs of pigs naturally infected with Leptospira $\mathrm{spp}$. ${ }^{*} \mathrm{p}=0.29$.

exposed to other serovars that did not belong to the collection of live antigens used in the MAT, the resulting antibody would not be detected. However, IHC allowed for the serovar-specific visualization of leptospire antigens. Another relevant factor is that IHC detected the antigen in tissues, while MAT detected circulating antibodies that, depending on the stage of infection, may no longer be present or may only be present at undetectable levels. A more detailed study evaluating the diagnostic methods for detecting an infection by leptospires will be important because the detection of an antigen in tissue by IHC has been shown to identify a greater number of infected pigs (Campos et al. 2011, Gonçalves et al. 2011); therefore, many pigs are being diagnosed as false negatives by MAT.

Leptospires are rarely detected in lung tissue by conventional methods or by immunohistochemistry and PCR. The lack of detection of leptospires in lung tissue suggests that leptospires pass through the lung and are transported by 
the bloodstream to organs, such as the kidney, where they are excreted in the urine to contaminate the environment. In the lung, it seems that leptospires are effectively eliminated by host defense systems, including macrophages, alveolar cells and the secretions of these cell types, leaving behind only leptospire antigens. It should be emphasized that the absence of clinical signs of infection in the infected pigs, as evidenced in this study, suggested an infection in the chronic phase, when there were no more leptospires in circulation. In this context, immunohistochemistry is an efficient method for identifying infection. In a case study involving three patients who died from leptospirosis (Silva et al. 2002), IHC was very useful in both the initial diagnosis and in identifying leptospire antigens in the affected areas, highlighting leptospire antigen importance in disease pathogenesis (Alves et al. 1989, Silva et al. 1995).

The Leptospira antigen was primarily located in areas of inflammatory infiltration, showing a relationship between the Leptospira antigen and lung lesions. This relationship has also been observed human infections (Croda et al. 2010). Thus, the inflammatory infiltrate and the Leptospira antigen were observed mainly in the alveolar septa, which appeared thickened due to hemorrhage. These results demonstrated that leptospiral antigen participates in the pathogenesis of lung injury during leptospirosis in pigs.

The polymerase chain reaction did not amplify leptospiral DNA in lung tissue, most likely due to presence of a reduced number of the bacteria in the lung, as has been observed in dog models (Klopfleisch et al. 2010). Under these circumstances, the pulmonary lesions could be caused by leptospiral toxins produced in distant organs, such as the liver (Miller et al. 1974). The results of this study demonstrated that the presence of leptospires could not be detected, only leptospire antigens. Similar results have been found in other studies (Pereira et al. 2005).

Although leptospiral DNA has not been detected during lung leptospirosis, leptospiral DNA has been found in renal tissue. Under experimental settings, leptospiral spreading to nearly all host tissues occurs during the initial phase of infection (Athanazio et al. 2008) followed, within a few days, by its disappearance from most tissues except for the kidney (Monahan et al. 2008). Therefore, PCR evaluation of a leptospiral lung infection did not provide good diagnostic results. This may be due to the presence of amplification inhibitors in the samples (Aviles et al. 1999), such as urea, creatinine, hemoglobin derivatives, collagen, proteases, polysaccharides, among others (Yersin et al. 1998) which has been observed in canine blood samples (Korfhagen et al. 1996).

The identification of ATII cells was performed using two antibodies: anti-TTF1 and anti-Napsin A. TTF1 (Thyroid Transcription Factor) is a major transcriptional regulator of a number of specific genes, including surfactant protein A (SP-A) (Korfhagen et al. 1996), which is synthesized in the lung, especially in ATII cells (Schuerman et al. 2008). Napsin $\mathrm{A}$ is an aspartic protease also expressed in the lung, especially in ATII cells and alveolar macrophages, as well as in the spleen and kidney. Napsin A is also excreted as a functional protease in the urine (Schauer-Vukasinovic et al. 2001).
Thus, the specific identification of ATII cells is an important step for studying protein components expressed by these cells, making it possible to evaluate their functional properties in animal models of pulmonary infectious diseases (Van Reeth et al. 1998). It should be noted that respiratory infections are not only an important human health problem but also a major obstacle in breeding pigs (Christensen et al. 1999). Although leptospirosis is not primarily transmitted through the respiratory tract, the lung is greatly affected by the infection.

The use of the two antibodies showed different results, as increased lung inflammation resulted in fewer ATII cells detected by immunostaining using the anti-TTF1 but greater numbers of cells detected by immunostaining with anti-Napsin A. This may be due to anti-Napsin A binding to alveolar type I cells and alveolar macrophages (Schauer-Vukasinovic et al. 1999). The finding that fewer alveolar cells were stained with TTF-1 during inflammation suggests that leptospires cause the injury of ATII cells when they leave the blood vessels to enter the pulmonary interstitium, leading to fewer of ATII cells. It is known that in humans (Croda et al. 2010) and canines (Klopfleisch et al. 2010), leptospirosis induce extensive necrosis of ATII cells when compared to uninfected controls. Other studies have shown that pathogenic Leptospira can reach the lung interstitium, causing reduced synthesis of endothelial cell cytoskeletal proteins, thus damaging the cells (Martinez-Lopez et al. 2010). This likely also occurs with ATII cells, although this aspect was not investigated during this study. Further studies are needed on the mRNA expression of surfactant proteins to better understand the role of ATII cells in the pathogenesis of lung injury in leptospirosis in pigs.

Complementing the main results of this study, we suggest that the use of anti-TTF-1 is more suitable for the identification of ATII cells than anti-Napsin A because the results with the latter antibody overestimated the number of cells, most likely because it also detected other alveolar cells.

There are no reports in the literature, the best of our knowledge, regarding the expression of TTF- 1 and Napsin A by pulmonary alveolar cells in individuals infected with Leptospira spp. However, studies focusing on the kidneys have shown decreased expression of Napsina A during chronic infection (Nally et al. 2011) and that this decrease is indicative of a tubular injury (Schauer-Vukasinovic et açl. 2001).

One study evaluating changes in the transcriptional activity of TTF-1 in murine lung clear cells by immunohistochemistry showed decreased expression following infection with gram-negative bacteria (Pseudomonas aerugino$s a)$, and TTF-1 expression was also markedly reduced in alveolar epithelial cells (Harrod et al. 2005). Similar results were found in this study, in which we observed a decrease in TTF-1 positive cells in the lungs of pigs infected with Leptospira spp., suggesting that the pulmonary inflammatory changes caused by the presence of leptospires or their toxins may damage ATII cells and lead to this decline. Given this assumption, a reduction in the number of ATII cells would interfere with their synthesis and secretion of col- 
lectins and surfactants, as well as with a reduction of the cytokines and chemokines normally secreted by these cells (Fehrenbach 2001), thus contributing to inflammatory lung injury. The infection decreased the defensive potential of the lung, including ATII cells, through a mechanism of inhibition of genes that express surfactant proteins $(\mathrm{Pu}-$ thothu et al. 2007). Abnormal surfactant levels and composition in humans have been associated with respiratory inflammation (Lewis \& Veldhuizen 2003) and pulmonary fibrosis (Gunther et al. 1999). In the present study, inflammatory infiltrates and thickening of the alveolar septa were observed at significantly higher intensities in infected pigs. Although the in vivo role of collectins in chronic lung disease is poorly understood, a deficiency in SP-D appears to be inversely proportional to inflammation (Noah, Murphy \& Alink 2003). In this study we observed a similar event, in which there was an inverse relationship between the presence of ATII cells, the cell type primarily responsible for surfactant synthesis (Keer 1999), and inflammatory cell infiltration of the lung. Further studies of ATII cells and their products in experimental models or in pathogen-free pigs will be needed to clarify the role of this cell type in the pathogenesis of lung injury during leptospirosis in pigs.

It should be emphasized that further advances in the identification of pigs infected with leptospires, characterizing the involvement of the lung, an organ that has major role in the productivity of pigs, and understanding the pathogenesis of the infectious agent may contribute to the introduction of appropriate measures for controlling and treating leptospire-infected swine herds.

\section{CONCLUSIONS}

The present study revealed that there was a relationship between a decrease in ATII cells and infection by leptospires.

This paper points to the importance of studying ATII cells as potential markers of the degree of innate immune activation in the lungs of pigs during leptospirosis.

Acknowledgements.- The eternal Dr. Francisco Assis Lima Costa (in memoriam) the teachings passed along my guidance, fundamental to my professional development. We thank the Laboratory of Immunopathology at the Institute of Tropical Medicine, University of São Paulo, for technical support. The Laboratory of Bacterial Diseases Reproduction of the Biological Institute of São Paulo. This study was supported by CNPq.

\section{REFERENCES}

Alves V.A.F., Sirqueira S.A.C. \& Pestana C.B. 1989. Patologia da leptospirose: análise crítica dos aspectos morfológicos e imuno-histoquímicos relevantes para a compreensão da patogenia. Revta Inst. Adolfo Lutz, São Paulo, 49:75-80.

Athanazio D.A., Silva E.F., Santos C.S., Rocha G.M., Vannier-Santos M.A., McBride A.J., Ko A.I. \& Reis M.G. 2008. Rattus norvegicus as a model for persistent renal colonization by pathogenic Leptospira interrogans. Acta Trop. 105:176-180.

Aviles H., Belli A., Armijos R., Monroy F.P. \& Harris E. 1999. PCR detection and identification of Leishmania parasites in clinical specimens in Ecuador: a comparison with classical diagnostic methods. J. Parasitol. 85:181-187.

Avrameas S. 1970. Immunoenzyme techniques: enzymes markers for the localization of antigens and antibodies. Int. Rev. Cytol. 27:349-385.

Campos A.P., Gonçalves L.M.F., Freire S.M., Leal L.M., Mineiro A.L.B.B. \&
Costa F.A.L. 2011. Aglutininas antileptospiras em suínos abatidos para consumo e associação ao comprometimento hepático e pulmonar. Revta Patol. Trop. 40:137-148.

Carvalho J.E.M., Moraes I.N., Ferreira A.S., Gomes R.L.C., Dalston M.O. \& Silva J.J.P. 2004. Estudo do lavado broncoalveolar em pacientes com comprometimento pulmonar na leptospirose. J. Bras. Pneumol. 30:134-139.

Christensen G., Sorensen V. \& Mousing J. 1999. Diseases of the respiratory system, p.913-940. In: Straw B.E., D’Allaire S., Mengeling W.L. \& Taylor D.J. (Eds), Diseases of Swine. Iowa State University Press, Ames.

Chroneos Z.C. 2010. Sever-Chroneos Z, Shepherd VL. Pulmonary Surfactant: an immunological perspective. Cell Physiol. Biochem. 25:13-26.

Crapo J.D., Barry B.E., Gehr P., Bachofen M. \& Weibel E.R. 1982. Cell number and cell characteristics of the normal human lung. Am. Rev. Respir. Dis. 26:332-337.

Croda J., Neto A.N., Brasil R.A., Pagliari C., Nicodemo A.C. \& Duarte M.I.S. 2010. Leptospirosis pulmonary haemorrhage syndrome is associated with linear deposition of immunoglobulin and complement on the alveolar surface. Clin. Microbiol. Infec. 16:6.

Cunningham A.C., Milne D.S., Wilkes J., Dark J.H., Tetley T.D. \& Kirby J.A. 1994. Constitutive expression of MHC and adhesion molecules by alveolar epithelial cells (type II pneumocytes) isolated from human lung and comparison with immunocytochemical findings. J. Cell Sci. 107:443449.

Debbabi H., Ghosh S., Kamath A.B., Alt J., Demello D.E., Dunsmore S. \& Behar S.M. 2005. Primary type II alveolar epithelial cells present microbial antigens to antigen-specific CD4_ T cells. Am. J. Physiol. Lung Cell. Mol. Physiol. 289:L274-L279.

Evans M.J. \& Hackney J.D. 1972. Cell proliferation in lungs of mice exposed to elevated concentrations of oxygen. Aerosp. Med. 43:620-622.

Faine S., Alder B., Bolin C. \& Perolat P. 1999. Leptospira and leptospirosis. 2nd ed. MediSci, Melbourne. 272p.

Fehrenbach H. 2001. Alveolar epithelial type II cell: defender of the alveolus revisited. Respir. Res. 2:33-46.

Ferrara N., Gerber H.P. \& Lecouter J. 2003. The biology of VEGF and its receptors. Nat. Med. 9:669-676.

Gonçalves L.M.F., Mineiro A.L.B.B., Carvalho S.M., Campos A.P., Melo Evangelista L.S., Pinho F.A., Moreira E.C. \& Costa F.A.L. 2011. Pesquisa de aglutininas, antígeno de leptospiras e apoptose em rim de suínos naturalmente infectados por Leptospira sp. Pesq. Vet. Bras. 31:561-568.

Gunther A., Schmidt R., Nix F., Yabut-Perez M., Guth C., Rosseau S., Siebert C., Grimminger F., Morr H., Velcovsky H.G. \& Seeger W. 1999. Surfactant abnormalities in idiopathic pulmonary fibrosis, hypersensitivity pneumonitis and sarcoidosis. Eur. Respir. J. 14:565-573.

Halliday H.L. 2008. Surfactants: Past, present and future. J. Perinatol. 28:47-56.

Harrod K.S., Jaramillo R.J., Berger J.A., Gigliotti A.P., Seilkop S.K. \& Reed M.D. 2005. Inhaled Diesel engine emissions reduce bacterial clearance and exacerbate lung disease to Pseudomonas aeruginosa infection in vivo. Toxicol. Sci. 83:155-165.

Herzog E.L., Brody A.R., Colby T.V., Mason R. \& Williams M.C. 2008. Knowns and unknowns of the alveolus. Proc. Am. Thorac. Soc. 5:778-782.

Kannan S., Huang H., Seeger D., Audet A., Yaoyu C., Canhua H., Hongwei G., Shaoguang L. \& Min W. 2009. Alveolar epithelial type II cells activate alveolar macrophages and mitigate P. aeruginosa infection. PloS One 4:e4891.

Keer M.H. 1999. Surfactant protein levels in severe respiratory syncytial virus infection. Am. J. Respir. Crit. Care Med. 159:1115-1118.

Klopfleisch R., Kohn B., Plog S., Weingart C., Nöckler K., Mayer-Scholl A. \& Gruber A.D. 2010. "An emerging pulmonary haemorrhagic syndrome in dogs: similar to the human leptospiral pulmonary haemorrhagic syndrome?" Vet. Med. Int. 27:928541.

Korfhagen T.R., Bruno M.D., Ross G.F., Huelsman K.M., Ikegami M., Jobe A.H., Wert S.E., Stripp B.R., Morris R.E., Glasser S.W., Bachurski C.J., Iwamoto H.S. \& Whitsett J.A. 1996. Altered surfactant function and structure in SP-A gene targeted mice. Proc. Natl Acad. Sci. USA 93:9594-9599. 
Lewis J.F. \& Veldhuizen R. 2003. The role of exogenous surfactant in the treatment of acute lung injury. Annu. Rev. Physiol. 65:613-642.

Lin C.L., Wu M.S., Yang C.W. \& Huang C.C. 1999. Leptospirosis associated with hypokalaemia and thick ascending limb dysfunction. Nephrol. Dial. Transplant. 14:193-195.

Luks A.M., Lakshminarayanan S. \& Hirschmann J.V. 2003. Leptospirosis presenting as diffuse alveolar hemorrhage: case report and literature review. Chest 123:639-643.

Martinez-Lopez D.G., Fahey M. \& Coburn J. 2010. Responses of Human Endothelial Cells to Pathogenic and Non-Pathogenic Leptospira Species. PLoS. Negl. Trop. Dis. 4:918.

Mérien F., Amouriaux P., Perolat P., Baranton G. \& Saint Girons I. 1992. Polymerase chain reaction for detection of Leptospira spp. in clinical samples. J. Clin. Microbiol. 30:2219-2224.

Miller N.G., Allen J.E. \& Wilson R.B. 1974. The pathogenesis of hemorrhage in the lung of the hamster during acute leptospirosis. Med. Microbiol. Immunol. 160:269-278.

Monahan A.M., Callanan J.J. \& Nally J.E. 2008. Proteomic analysis of Leptospira interrogans shed in urine of chronically infected hosts. Infect. Immun. 76:4952-4958.

Naiman B.M., Blumerman S., Alt D., Bolin C.A., Brown R., Zuerner R. \& Baldwin C.L. 2002. Evaluation of type 1 immune response in naïve and vaccinated animals following challenge with Leptospira borgpetersenii serovar Hardjo: involvement of WC1(+) gammadelta and CD4 T cells. Infect. Immun. 70:6147-6157.

Nakane P.K. \& Pierce G.B. 1966. Enzyne labeled antibodies: preparation and application for the localization of antigens. J. Histochem. Cytochem. 14:929-931.

Nally J.E., Monahan A.M., Miller I.S., Bonilla-Santiago R., Souda P. \& Whitelegge J.P. 2011. Comparative Proteomic Analysis of Differentially Expressed Proteins in the Urine of Reservoir Hosts of Leptospirosis. PloS One. 6:e26046.

Noah T.L., Murphy P.C. \& Alink J.J. 2003. Bronchoalveolar lavage fluid surfactant protein-A and surfactant protein-D are inversely related to inflammation in early cystic fibrosis. Am. J. Respir. Crit. Care. Med. 168:685-691.

Pereira M.M., Da Silva J.J., Pinto M.A., Da Silva M.F., Machado M.P., Lenzi H.L. \& Marchevsky R.S. 2005. Experiment a lleptospirosis in marmoset monkeys (Callithrix jacchus): a new model for studies of severe pulmonary leptospirosis. Am. J. Trop. Med. Hyg. 72:13-20.

Puthothu B., Forster J., Heinze J., Heinzmann A. \& Krueger M. 2007. Surfactant protein B polymorphisms are associated with severe respiratory syncytial virus infection, but not with asthma. BMC. Pulm. Med. 7. doi:10.1186/1471-2466-7-6
Richtzenhain L.J., Cortez A., Heinemann M.B., Soares R.M., Sakamoto S.M., Vasconcellos S.A., Higa Z.M., Scarcelli E. \& Genovez M.E. 2002. A multiplex PCR for the detection of Brucella spp. And Leptospira spp. DNA from aborted bovine fetuses. Vet. Microbiol. 87:139-147.

Russell B.H., Vasan R., Keene D.R., Koehler T.M. \& Xu Y. 2008. Potential dissemination of Bacillus anthracis utilizing human lung epithelial cells. Cell. Microbiol. 10:945-957.

Schauer-Vukasinovic V., Bur D., Kling D., Grüninger F. \& Giller T. 1999. Human Napsin A: expression, immunochemical detection, and tissue localization. Fed. Eur. Biochem. Soc. 462:135-139.

Schauer-Vukasinovic V., Langen H. \& Giller T. 2001. Detection of immunoreactive napsin A in human urine. Biochim. Biophys. Acta 1524:51-56.

Schuerman F.A., Griese M., Gille J.P., Brasch F., Noorduyn L.A. \& Van Kaam A.H. 2008. Surfactant protein b deficiency caused by a novel mutation involving multiple exons of the sp-b gene. Eur. J. Med. Res. 13:281-286.

Silva J.J., Dalston M.O., Carvalho J.E., Setúbal S., Oliveira J.M. \& Pereira M.M. 2002. Clinicopathological and immunohistochemical features of the severe pulmonary form of leptospirosis. Revta Soc. Bras. Med. Trop. 35:395-399.

Silva J.J.P., Souza Neto B.A., Lilembaum W., Alvim M.E.A.M.V. \& Oliveira A.V. 1995. The hemorrhagic syndrome of leptospirosis: an experimental study in guinea pigs. Revta Soc. Bras. Med. Trop. 28:169-177.

Singh G., Katyal S.L., Brown W.E., Collins D.L. \& Mason R.J. 1988. Pulmonary lysozyme: a secretory protein of type II pneumocytes in the rat. Am. Rev. Respir. Dis. 138:1261-1267.

Uhal B.D. 1997. Cell cycle kinetics in the alveolar epithelium. Am. J. Physiol. 272: L1031-L1045.

Van Reeth K., Nauwynck H. \& Pensaert M. 1998. Bronchoalveolar interferon-alpha, tumor necrosis factor-alpha, interleukin-1, and inflammation during acute influenza in pigs: a possible model for humans? J. Infect. Dis. 177:1076-1079.

Werts C., Tapping R.I., Mathison J.C., Chuang T.H., Kravchenko V., Saint Girons I., Haake D.A., Godowski P.J., Hayashi F., Ozinsky A., Underhill D.M., Kirschning C.J., Wagner H., Aderem A., Tobias P.S. \& Ulevitch R.J. 2001. Leptospiral lipopolysaccharide activates cells through a TLR2-dependent mechanism. Nat. Immunol. 2:346-352.

Yersin C., Bovet P., Merien F., Wong T., Panowsky J. \& Perolat P. 1998. Human leptospirosis in thenSeychelles (Indian Ocean): a population-based study. Am. J. Trop. Med. Hyg. 59:933-939.

Zissel G., Ernst M., Rabe K., Papadopoulos T., Magnussen H., Schlaak M. \& Müller-Quernheim J. 2000. Human alveolar epithelial cells type II are capable of regulating T-cell activity. J. Investig. Med. 48:66-75. 